\title{
Abnormal PAP Smear
}

National Cancer Institute

\section{Source}

National Cancer Institute. Abnormal PAP Smear. NCI Thesaurus. Code C127841.

A finding indicating the presence of abnormal cervical cells in a Pap smear. 